\title{
Спосіб лікування остеомієліту п’яткової кістки у хворих на нейропатичну форму синдрому діабетичної стопи
}

\begin{abstract}
Мета роботи: поліпшити результати лікування, знизити кількість післяопераційних ускладнень, скоротити терміни стаціонарного лікування хворих з остеомієлітом п’яткової кістки на тлі нейропатичної форми синдрому діабетичної стопи завдяки застосуванню запропонованої методики модифікованого операційного лікування.

Матеріали і методи. Дослідження проводили на базі відділення гнійно-септичної хірургії Міської клінічної лікарні № 11 м. Одеси. У дослідження включені пацієнти, які хворіють на цукровий діабет типу 2 з нейропатичною формою синдрому діабетичної стопи. У всіх випадках гнійно-некротичний процес локалізувався в ділянці п’яти з ураженням п’яткової кістки. Впродовж 20142020 pр. ми спостерігали пацієнтів з остеомієлітом п’яткової кістки на тлі нейропатичної діабетичної стопи. Пацієнтів розділили на дві групи. Першу групу склали 24 пацієнти з остеомієлітом п’яткової кістки, оперованих за запропонованою методикою. 3 метою стимуляції репаративних процесів у тканинах ми використовували інтраопераційну інфільтрацію шкірно-м’язових клаптів збагаченою тромбоцитами плазмою. Друга групу сформували на підставі ретроспективного аналізу історій хвороби 32 пацієнтів, які отримували лікування за загальноприйнятими методиками.

Результати досліджень та їх обговорення. Застосування запропонованого методу лікування остеомієліту п’яткової кістки дало змогу знизити кількість післяопераційних ускладнень з 25 до 8,2 \%, скоротити середній термін перебування пацієнта в стаціонарі $3(29,4 \pm 6,2)$ до $(17,14 \pm 5,2)$ дня, а також внаслідок більш ефективного лікування остеомієліту п’яткової кістки зберегти опороспроможність кінцівки, поліпшити якість життя пацієнтів. Відсутність післяопераційних гематом у пацієнтів першої групи ми пов'язуємо із застосуванням розробленої методики «пломбування» залишкових порожнин, яку ми розробили, що запобігає скупченню ексудату з наступним його нагноєнням. Інтраопераційна інфільтрація тканин збагаченої тромбоцитами плазми, що містить не тільки фактори росту, але й адгезивні молекули і цитокіни, що стимулюють репараційні й анаболічні процеси в пошкоджених тканинах, стимулює неоангіогенез, зменшує ймовірність розвитку вторинних некрозів у рані.
\end{abstract}

Ключові слова: синдром діабетичної стопи; остеомієліт п’яткової кістки; збагачена тромбоцитами плазма.

Постановка проблеми і аналіз останніх досліджень та публікацій. У структурі захворюваності жителів економічно розвинених країн цукровий діабет (ЦД) займає одне з перших місць і становить 1,5-6 \% [1]. Ураження нижніх кінцівок різного генезу діагностують у 30-80 \% осіб із порушеним вуглеводним обміном [7]. Остеомієліт $€$ поширеним ускладненням синдрому діабетичної стопи, більшості великих і малих ампутацій передує остеомієлітичне ураження кісток стопи. Ризик ампутації при гострій інфекції в чотири рази перевищує такий з остеомієлітом, ніж при ураженні тільки м’яких тканин [8]. На відміну від гематогенного остеомієліту (поширення через кровотік) і прямого інфікування (при переломах) при діабетичній стопі відбувається контактне поширення збудника з інфекційного вогнища, що ускладнює виразковий дефект. Остеомієліт є типовим ускладненням синдрому діабетичної стопи [5].

На даний час при наявності остеомієліту п'яткової кістки виконують часткове або субтотальне видалення з подальшим ушиванням рани або закриттям дефекту клаптем [9]. Недоліком відкритого ведення рани є висока ймовірність рецидиву гнійно-некротичного процесу з формуванням флегмони, а також в більшості випадків, загоєння рани. Трабекулярна структура і великий обсяг губчастої речовини п'яткової кістки призводять до швидкого поширення в ній остеомієлітичного процесу.

Використання збагаченої тромбоцитами плазми для прискорення росту кістки і м'яких тканин на сьогодні стало одним із напрямків у реконструктивно-відновній хірургії. Тромбоцити здатні вивільняти велику кількість високоактивних компонентів, біологічних субстанцій, специфічних і неспецифічних факторів росту [10], що ініціюють мітогенез і проявляють сприятливий вплив на процеси регенерації кісткової [6], м’язової [3], сухожильной [2] та інших різновидів сполучної тканини і клітин організму. Велика концентрація в тромбоцитах білків, про- і антизапальних цитокінів, факторів росту [4], автологічність сприяла застосуванню збагаченої тромбоцитами плазми в різних сферах медицини.

Мета роботи: поліпшити результати лікування, знизити кількість післяопераційних ускладнень, скоротити терміни стаціонарного лікування хворих з остеомієлітом п’яткової кістки на тлі нейропатичної форми синдрому діабетичної сто- 
пи завдяки застосуванню запропонованої методики модифікованого операційного лікування.

Матеріали і методи. Дослідження проводили на базі відділення гнійно-септичної хірургії Міської клінічної лікарні № 11 м. Одеси. У дослідження включені пацієнти, які страждають від цукрового діабету 2 типу з нейропатичною формою синдрому діабетичної стопи. Тактильну і вібраційну чутливість оцінювали за стандартним монофіламентом Touch Test 8 г і камертона з частотою 126 Гц. Для оцінки стану периферичного кровообігу виконували дуплексне дослідження артерій нижніх кінцівок на апараті Siemens ACUSON S2000. У всіх пацієнтів відзначали магістральний кровотік у всіх відділах кінцівки аж до артерій стопи.

У всіх розглянутих випадках гнійно-некротичний процес розташовувався в ділянці п’яти 3 ураженням п'яткової кістки. Діагноз остеомієліту встановлювали на підставі даних рентгенографічного дослідження, при необхідності уточнювали MPТ дослідженням, виконували патогістологічне дослідження резектованої кісткової тканини, лабораторне бактеріологічне дослідження.

Усіх пацієнтів розділили на дві групи. Першу групу склали 24 пацієнти з остеомієлітом п’яткової кістки, які проходили стаціонарне лікування в період з 2014 до 2020 р., оперованих за запропонованою методикою. Другу групу склали на підставі ретроспективного аналізу історій хвороби 32 пацієнтів, які отримували лікування за загальноприйнятими методиками (табл. 1).

У мікробіологічному дослідженні в обох групах переважали S.aureus близько 43 \% в першій групі, 41 \% - у другій групі і Enterobacteiaceae 46 \% у першій групі і 44 \% - у другій групі.

Таблиця 1. Мікробна етіологія остеомієліту п'яткової кістки в пацієнтів

\begin{tabular}{|c|c|c|}
\hline Мікроорганізми & Перша група, \% (n=24) & Друга група, \% (n=32) \\
\hline \multicolumn{3}{|c|}{ Аеробні грампозитивні коки } \\
\hline Staphylococcus aureus & 42 & 41 \\
\hline Staphylococcus epidermidis & 37 & 38 \\
\hline Enterococcus species & 46 & 44 \\
\hline Corynebacterium species & 17 & 16 \\
\hline \multicolumn{3}{|c|}{ Аеробні грамнегативні палички } \\
\hline Enterobacteriaceae & 46 & 44 \\
\hline Pseudomonas species & 8 & 9 \\
\hline \multicolumn{3}{|c|}{ Облігатні анаероби } \\
\hline Peptococci u peptostreptococci & 25 & 25 \\
\hline Інші види & 25 & 28 \\
\hline Полімікробні асоціації & 71 & 72 \\
\hline
\end{tabular}

Примітка: загальна кількість перевищує 100 \% внаслідок наявності полімікробних асоціацій.

У передопераційному періоді пацієнти обох груп проходили стандартні обстеження: клініко-лабораторні, рентгенологічні дослідження, ЕКГ. Проводили корекцію глікемії шляхом введення інсулінів короткої дії; корекцію супутніх захворювань.

Вік хворих першої групи варіював від 28 року до 79 років (середній вік склав 56,9 $\pm 8,7$ ). 3 усіх пацієнтів 12,5 \% становили хворі з ЦД 1 типу і $87,5 \%$ - $з$ ЦД 2.
У другій групі середній вік склав $(58,5 \pm 6,5)$ року, також переважали пацієнти ЦД 2 типу 12,5 \%, ЦД 1 типу $-87,5 \%$.

Тяжку форму дистальної діабетичної полінейропатії діагностовано в 94,6 \% випадків у першій групі, 87,5 \% - у другій групі, діабетичну ретинопатію - в 79,1 \% (з них проліферативну - у 5,6 \%) в першій групі, 75 \% - у другій групі. Діабетичну нефропатію на стадії протеїнурії діагно- 
стували в 50 \% хворих і 56,25 \% відповідно. Хворих із термінальною стадією ХНН у дослідження не включали.

Супутні соматичні захворювання практично однаково представлені в обох групах (табл. 2).
Пацієнти з компенсованим цукровим діабетом склали 23,5 \%, стадію субкомпенсації діагностовано у 58,8 \%, декомпенсації - у 16,7 \%. У другій групі стадія компенсації - $25 \%$, субкоменсації 62,5 \%, декомпенсації - 12,5 \%.

Таблиця 2. Порівняльний аналіз груп пацієнтів із супутньою патологією

\begin{tabular}{|c|c|c|}
\hline Супутня патологія & Перша група, \% (n=24) & Друга група, \% (n=32) \\
\hline Ішемічна хвороба серця & 66,7 & 71,8 \\
\hline Гіпертонічна хвороба & 83,3 & 84,3 \\
\hline $\begin{array}{l}\text { Гостре порушення мозкового } \\
\text { кровообігу (в анамнезі) }\end{array}$ & 12,5 & 9,3 \\
\hline Інфаркт міокарда в анамнезі & 20,8 & 21,8 \\
\hline $\begin{array}{l}\text { Хронічна діабетична нефропатія на } \\
\text { стадії протеїнурії }\end{array}$ & 50 & 56,25 \\
\hline $\begin{array}{l}\text { Хірургічні втручання з приводу } \\
\text { ускладнень СДС (в анамнезі) }\end{array}$ & 20,8 & 25 \\
\hline $\begin{array}{l}\text { Декомпенсація ЦД на момент } \\
\text { надходження в стаціонар }\end{array}$ & 16,7 & 12,5 \\
\hline
\end{tabular}

Розмір виразкового дефекту п’яткової ділянці в першій групі склав $16 \mathrm{~cm}^{2}$ в діаметрі у 4 пацієнтів, до $12 \mathrm{~cm}^{2}$ - у 6 пацієнтів і у 14 пацієнтів - до 7 см² $^{2}$ У другій групі 16 см² $^{2} 5$ пацієнтів, до 12 см$^{2}$ - 14 пацієнтів, до 7 см $^{2}-13$ пацієнтів. За віковим складом, супутньою патологією, тяжкістю ранового процесу дані групи порівнювали.

У першій групі в два етапи прооперовано 2 пацієнтів, госпіталізованих стадії декомпенсації, з флегмоною п'яткової ділянки. Решту пацієнтів прооперовано одномоментно після передопераційної підготовки, спрямованої на усунення гострого запального процесу, що включала санацію рани, антибактеріальну терапію. Ми проводили операційне втручання за запропонованою методикою - патент № 109509 від 25.08.2015 р. Після купірування гострого гнійного запалення проводили висікання виразкового дефекту п’яткової ділянки, остеомієлітичну порожнину обробляли фрезою до здорових тканин. Далі розріз продовжували по медіальній, серединній, або латеральній поверхні стопи. Вибір доступу залежав від локалізації виразки. Частково висікали підошовний апоневроз і залежно від доступу вибирали один із трьох м'язів (m. Flexor digitorum brevis, $\mathrm{m}$. Abductor hallucis, m.abductor digiti minimi), дистальний відділ відсікали і проводили ним там- понаду, що утворилася після некректомії порожнини в п’яткової кістки.

Після видалення апоневрозу, запалених тканин і частини п'яткової кістки утворюється “вільне місце” і шкірні шви вдається накласти без натягу.

3 метою стимуляції репаративних процесів у тканинах ми використовували інтраопераційну інфільтрацію шкірно-м'язових клаптів збагаченою тромбоцитами плазмою. Плазму виготовляли з крові пацієнта безпосередньо перед введенням за допомогою апарату “SmartPrep” (фірма виробник Harvest Corp. USA, свідоцтво про реєстрацію № 10179 / 2011, згідно з наказом Держклінінспекції МОЗ України від 8 лютого 2011 р. № 69). Інфільтрацію виконували шляхом дробного введення плазми в тканини.

У післяопераційному періоді з метою іммобілізації ураженої кінцівки використовувалися накладну гіпсову лонгету.

Результати досліджень та їх обговорення. При застосуванні запропонованої методики у 24 пацієнтів першої групи вдалося зашити рану наглухо. Летальних випадків не спостерігали.

Кількість післяопераційних ускладнень склала 2 (8,2 \%). В обох випадках спостерігали нагноєння післяопераційної рани, які були купірувані консервативними методами. Гематом післяопераційної 


\section{з ДОСВІДУ РОБОТИ}

рани і формування вторинного некрозу країв рани не спостерігали.

Тривалість післяопераційного перебування хворих в стаціонарі склало $(17,14 \pm 5,2)$ дня.

У другій групі ускладнення зафіксовані у 8 хворих (25\%). У 3 пацієнтів спостерігали нагноєння післяопераційної рани, у 4 - післяопераційні гематоми, що потребували дренування і подальшого загоєння ран вторинним натягом, в одного пацієнта відзначали явища вторинного некрозу країв рани. Тривалість перебування в стаціонарі у хворих другої групи склала $(29,4 \pm 6,2)$ дня.

Відсутність післяопераційних гематом у пацієнтів першої групи ми пов’язуємо із застосуванням розробленої методики “пломбування” залишкових порожнин, що запобігає скупченню ексудату

\section{СПИСОК ЛІТЕРАТУРИ}

1. Балаболкин М. И. Диабетология / М. И. Балаболкин. Москва : Медицина, 2000. - 672 с.

2. Andia I. Tendon healing and platelet-rich plasma therapies / I. Andia, M. Sanchez, N. Maffulli // Exp. Opin. Biol. Ther. - 2010. - Vol. 10, No. 10. - P. 1415-1426.

3. Platelet-rich plasma in muscle healing / P. Borrione, A. D. Gianfrancesco, M. T. Pereira, F. Pigozzi // Am. J. Phys. Med. Rehabil. - 2010. - Vol. 89, No. 10. - P. 854-861.

4. Frechette J.-P. Platelet-rich plasmas: growth factor content and roles in wound healing / J.-P. Frechette, I. Martineau, G. Gagnon // J. Dent. Resistant. - 2005. - Vol. 84. - P. 434.

5. Game F. L. Osteomyelitis in the diabetic foot: diagnosis and management / F. L. Game // Med. Clin. North Am. - 2013. Vol. 97. - P. 947-956.

6. Effect of platelet-rich plasma on periimplant bone repair: a histologic study in dogs / R. V. Garcia, M. A. Gabrielli,

\section{REFERENCES}

1. Balabolkin, M.I., Diabetologiya [Diabetology]. Moscow: Meditsina [in Russian].

2. Andia, I., Sanchez, M., \& Maffulli N. (2010). Tendon healing and platelet-rich plasma therapies. Exp. Opin. Biol. Ther., 10 (10), 1415-1426.

3. Borrione, P., Gianfrancesco, A.D., Pereira, M.T., \& Pigozzi, F. (2010). Platelet-rich plasma in muscle healing. Am. J. Phys. Med. Rehabil., 89 (10), 854-861.

4. Frechette, J.-P., Martineau, I., \& Gagnon, G. (2005). Plateletrich plasmas: growth factor content and roles in wound healing. J. Dent. Resistant., 84, 434.

5. Game, F.L. (2013). Osteomyelitis in the diabetic foot: diagnosis and management. Med. Clin. North Am., 97, 947-956.

6. Garcia, R.V., Gabrielli, M.A., \& Hochuli-Vieira, E. (2010).
3 наступним його нагноєнням. Інтраопераційна інфільтрація тканин збагаченої тромбоцитами плазми, що містить не тільки фактори росту, але й адгезивні молекули і цитокіни, що стимулюють репараційні й анаболічні процеси в пошкоджених тканинах, стимулює неоангіогенез, зменшує ймовірність розвитку вторинних некрозів у рані.

Висновки. Застосування запропонованого методу дало змогу знизити кількість післяопераційних ускладнень 325 до 8,2 \%, скоротити середній термін перебування пацієнта в стаціонарі з (29,4 \pm $6,2)$ до $(17,14 \pm 5,2)$ дня, а також внаслідок більш ефективного лікування остеомієліту п'яткової кістки зберегти опорну здатність кінцівки, поліпшити якість життя пацієнтів.
E. Hochuli-Vieira [et al.] // J. Oral. Implantol. - 2010. - Vol. 36, No. 4. - P. 281-290.

7. Definitions and guidelines for assessment of wounds and evaluation of healing / G. S. Lasarus, D. M. Cooper, D. R. Knighton [et al.] // Arch. Dermatolol. - 1994. - Vol. 130. - P. 489-493.

8. The implications of the presence of osteomyelitis on outcomes of infected diabetic foot wounds / M. Mutluoglu, A. K. Sivrioglu, M. Eroglu [et al.] // Scand. J. Infect. Dis. - 2013. - Vol. 45 (7). P. 497-503

9. Nather A. The diabetic foot / A. Nather. - Singapore: World Scientific; 2013.

10. Zhao Y. Research progress of platelet-rich plasma in promoting bone regeneration and repairing / Y. Zhao, W. Zhai // Zhongguo Xiu Fu Chong Jian Wai Ke Za Zhi. - 2010. - Vol. 24, No 8. - P. 1004-1008.

Effect of platelet-rich plasma on periimplant bone repair: a histologic study in dogs. J. Oral. Implantol., 36 (4), 281-290.

7. Lasarus, G.S., Cooper, D.M., \& Knighton, D.R. (1994). Definitions and guidelines for assessment of wounds and evaluation of healing. Arch. Dermatolol., 130, 489-493.

8. Mutluoglu, M., Sivrioglu, A.K., \& Eroglu, M. (2013). The implications of the presence of osteomyelitis on outcomes of infected diabetic foot wounds. Scand. J. Infect. Dis., 1; 45 (7), 497-503.

9. Nather, A. (2013). The diabetic foot. Singapore: World Scientific.

10. Zhao, Y., \& Zhai, W. (2010). Research progress of platelet-rich plasma in promoting bone regeneration and repairing. Zhongguo Xiu Fu Chong Jian Wai Ke Za Zhi, 24 (8), 1004-1008.

Отримано 17.06.2021 


\section{U. V. GRUBNIK, M. U. HOLOVCHENO, E. A. ANCYPOVICH}

Odesa National Medical University

\section{METHOD OF TREATMENT OF CALCANEUS OSTEOMYELITIS IN PATIENTS WITH NEUROPATHIC FORM OF DIABETIC FOOT SYNDROME}

The aim of the work: to improve results of treatment, to reduce quantity of postoperative complications, to reduce terms of inpatient treatment of patients with osteomyelitis of a heel bone with neuropathic form of diabetic foot syndrome due to application of the technique of the modified operative treatment offered by us.

Materials and Methods. The research was carried out in Septic Surgery of Odesa City Clinical Hospital No. 11. The patients with diabetes, type 2, with a neuropathic form of diabetic foot syndrome were included in research. In all the cases we saw a purulent-necrotic process in the area of calcaneus. Throughout 2014-2020, we observed patients with osteomyelitis of the calcaneus. Group 1 included 24 patients with osteomyelitis of the calcaneus, who were operated according to technique proposed by us. In order to stimulate reparative processes in the tissues, musculocutaneous flaps intraoperatively were infiltrated with platelets reached plasma. Another group was put on the submission of a retrospective analysis of the history of 32 patients, who were treated with the use of common methods.

Results and Discussion.

The use of the proposed method for the treatment of calcaneal osteomyelitis made it possible to reduce the number of postoperative complications from $25 \%$ to $8.2 \%$, to reduce the average length of hospital stay from (29.4 \pm 6.2$)$ to (17.14 \pm 5.2$)$ days, as well as due to more effective treatment of osteomyelitis of the calcaneus to preserve the support ability of the limb, improve the quality of life of patients. We associate the absence of postoperative hematomas in the patients of group 1 with the use of the technique developed by us for "filling" the residual cavities, preventing the accumulation of exudate with its subsequent suppuration. Intraoperative tissue infiltration of platelet-rich plasma containing not only growth factors, but also adhesive molecules and cytokines that stimulate repair and anabolic processes in damaged tissues, stimulates neoangiogenesis, and reduces the likelihood of secondary necrosis in the wound.

Key words: diabetic foot syndrome; osteomyelitis of the calcaneus; platelet-rich plasma. 